\begin{tabular}{|c|c|c|c|c|}
\hline JURNAL & \multirow{2}{*}{ VOLUME 3} & NOMOR 1 & HALAMAN 14-24 & $\begin{array}{l}\text { ISSN 2655-8823 }(p) \\
\text { ISSN 2656-1786 }(e)\end{array}$ \\
KOLABORASI RESOLUSI KONFLIK
\end{tabular}

\title{
HUBUNGAN PROSES PERKEMBANGAN PSIKOLOGIS REMAJA DENGAN TAWURAN ANTAR REMAJA
}

\author{
Muhammad Daffa Rizqi Eko Putra \\ Program Studi Sarjana Kesejahteraan Sosial FISIP Unpad \\ E-mail: muhammad19019@mail.unpad.ac.id \\ Nurliana Cipta Apsari \\ Pusat Studi CSR, Kewirausahaan Sosial dan Pemberdayaan Masyarakat FISIP Unpad \\ E-mail: nurliana.cipta.apsari@unpad.ac.id
}

\begin{abstract}
ABSTRAK
Artikel ini membahas tentang hubungan antara proses perkembangan psikologis individu pada tahap remaja dengan kenakalan remaja khususnya tawuran. Kami juga membahas tentang latar belakang remaja melakukan tawuran dan pencegahan yang dapat dilakukan. Metode yang digunakan dalam penulisan artikel ini adalah metode kualitatif dengan menggunakan studi kepustakaaan dengan menggunakan perspektif perkembangan manusia. Remaja merupakan individu berusia 13-21 tahun yang merupakan perlihan dari anak-anak menuju dewasa yang ditandai dengan pubertas. Pada tahapan ini menunjukkan bahwa proses perkembangan remaja terjadi perubahan baik secara fisik, mental, dan sosial. Kesimpulan penelitian ini menunjukkan bahwa proses perkembangan individu pada tahap remaja berhubungan dengan perilaku tawuran antar remaja. Krisis identitas yang sedang mereka alami merupakan salah satu proses yang menyebabkan mereka masih mencari jawaban atas pertanyaan yang ada tentang masalahnya. Selain itu, kondisi emosional mereka yang belum stabil dan masih meledak-ledak juga faktor yang menyebabkan mereka melakukan tawuran antar pelajar.
\end{abstract}

Kata kunci: kenakalan remaja, tawuran pelajar, perkembangan psikologi, perspektif perkembangan, masa remaja.

\section{PENDAHULUAN}

Remaja merupakan generasi penerus bangsa, mereka merupakan aset calon pemimpin bangsa di masa yang akan datang. Remaja merupakan masa peralihan dari anak-anak menjadi dewasa, rentang umur mereka adalah 12-21 tahun atau yang masih menduduki bangku sekolah (Riswanto, 2019), tahapan ini dimulai dengan pubertas ditandai dengan terjadinya nocturnal emission (mimpi basah) pada laki-laki dan menarche (menstruasi). Menurut data Badan Pusat Statistik (BPS) tahun 2019, Indonesia remaja merupakan populasi tertinggi dalam masyarakat Indonesia (R. Agustina et al., 2019), Penting bagi pemerintah untuk memaksimalkan potensi yang dimiliki oleh negara agar menciptakan generasi yang positif dan mencegah terjadinya kenakalan remaja. Menurut Santrock (2003) perubahan yang terjadi pada tahapan ini meliputi perubahan biologis, kognitif, dan sosial-emosional (Artini, 2018). Remaja merupakan fase dimana individu mencari identitas dirinya, sehingga akan banyak mengambil pengaruh melalui lingkungan pergaulannya (A. Agustina \& Appulembang, 2017). Menurut penelitian dikatakan bahwa teman sebaya merupakan pengaruh terbesar dalam perilaku kenakalan remaja (Tianingrum \& Nurjannah, 2020). Banyak remaja bahkan anak dibawah umur yang sudah mengenal tawuran, rokok, narkoba, dan perilaku lain yang menyimpang dari nilai dan norma yang berlaku dalam masyarakat hingga harus berurusan dengan hukum (Unayah \& Sabarisman, 2015)

Tawuran pelajar merupakan salah satu kenakalan remaja yang menarik untuk dibahas. Tawuran pelajar sendiri merupakan berkelahinya dua kelompok siswa atau pelajar secara bersamaan disertai dengan kata-kata cacian dan merendahkan terhadap kelompok lawan (Kurniawan et 


\begin{tabular}{|c|c|c|c|c|}
\hline JURNAL & \multirow{2}{*}{ VOLUME 3} & \multirow{2}{*}{ NOMOR 1} & HALAMAN 14-24 & $\begin{array}{l}\text { ISSN 2655-8823 }(p) \\
\text { ISSN 2656-1786 }(e)\end{array}$ \\
\hline
\end{tabular}

al., 2009). Menurut data yang dikeluarkan oleh KPAI sepanjang tahun 2018 terjadi kenaikan angka tawuran sebesar 1,1\%, tahun 2017 angka tawuran sebesar 12,9\% sedangkan tahun 2018 sebesar 14\%. Tawuran pelajar masih sering terjadi di Indonesia bahkan di tengah kondisi pandemi seperti ini. Seperti yang terjadi di Depok, diberitakan oleh Kompas.com dengan judul "Remaja Tewas Dibacok Dalam Tawuran di Tengah Pandemi Covid19” (Mantalean, 2020) Tawuran antarkelompok remaja terjadi di Jalan Raya Mangga, Pancoran Mas, Depok, Jawa Barat, pada Kamis (1/10/2020) sore. Kejadian ini menewaskan satu pemuda yang tertinggal oleh kelompoknya, ia dibacok dengan benda tajam di leher, kejadian ini terjadi pukul 16.50 WIB. Kemudian dua orang ditangkap dan dibawa ke Kapolsek Pancoran mas. Ditemukan sejumlah celurit dari dua pelajar tersebut dan sejumlah ponsel, hingga saat ini polisi masih mencari identitas kedua pelajar tersebut. Kejadian ini membuktikan bahwa tawuran dapat terjadi kapanpun dan dimanapun padahal pelajar sedang melakukan sekolah dari rumah di karenakan pandemi, tetapi tawuran antar pelajar tetap terjadi, seharusnya kita semua berada dirumah untuk mencegah terjadinya penularan virus.

Apabila remaja gagal dalam mengembangkan identitas dirinya maka akan terjadi penyimpangan dalam perilakunya dengan melakukan tindakan kriminal atau menutup diri dari masyarakat (Elhesmi et al., 2013). Perilaku tawuran pelajar merupakan budaya yang sudah turun-temurun, sehingga dapat terjadi kapanpun, dan diperkuat oleh rasa solidaritas, sehingga mereka akan melakukan pembalasan walaupun hanya masalah pribadi (Basri, 2015). Hal tersebut terjadi karena adanya ketakutan ditolak atau tidak diterima oleh kelompok sebayanya apabila tidak mengikutinya (Kurniawan et al., 2009). Kelompok pelajar menganggap kelompoknya sebagai in-group melihat lawan mereka sebagai musuh atau out- group (Kurniawan et al., 2009). Antar kelompok yang berlawanan telah memiliki prasangka yang buruk, prasangka merupakan penilaian terhadap individu atau kelompok yang didasarkan pada keanggotan terhadap anggota tersebut (Kurniawan et al., 2009). Tawuran pelajar sendiri tidak hanya dianggap sebagai kenakalan remaja, namun sebagai tindakan kriminalitas karena selain mereka menyerang lawannya, mereka juga merusak fasilitas umum karena dilakukan di jalanan umum dan bahkan, hingga menyebabkan adanya korban jiwa, dalam aspek kriminilogis tawuran antar pelajar termasuk kejahatan kekerasan kolektif yang karakter spesifiknya adalah agresivitas (Anjari, 2013). Pelajar yang melakukan tawuran tidak hanya menggunakan tangan kosong dalam melakukan aksinya, namun menggunakan senjata tajam seperti, batu, celurit, pisau lipat, dll. Korban jiwa akibat tawuran antar pelajar tidak hanya satu atau dua, menurut data Komisi Nasional Perlindungan anak pada tahun 2011 telah terjadi 339 kasus tawuran antar pelajar dan terdapat 82 korban jiwa di dalamnya (Basri, 2015). Penyebab tawuran pelajar bisa berasal dari faktor internal dan eksternal, faktor internal berupa kesalahan dalam menginternalisasi nilai-nilai yang ada disekitarnya, sedangkan eksternal disebabkan oleh pengaruh lingkungan tampat individu berkembang (Basri, 2015). Tulisan ini diharapkan memberi penjelasan mengenai hubungan perkembangan pada masa remaja dengan tawuran antar remaja.

\section{METODE}

Metode yang digunakan dalam penulisan artikel ini adalah metode kualitatif dengan menggunakan studi kepustakaan. Studi kepustakaan merupakan cara pengumpulan data dengan mempelajari literatur, paket modul dan panduan, buku-buku pedoman, buku-buku perpustakaan dan seaga bentuk kepustakaan lainnya yang dianggap mendukung (Arif et al., 2013). Cara yang dilakukan dalam melakukan studi 


\begin{tabular}{|c|c|c|c|c|}
\hline JURNAL & \multirow{2}{*}{ VOLUME 3} & \multirow{2}{*}{ NOMOR 1 } & HALAMAN 14-24 & $\begin{array}{l}\text { ISSN 2655-8823 }(p) \\
\text { ISSN 2656-1786 }(e)\end{array}$ \\
KOLABORASI RESOLUSI KONFLIK & ISS \\
\hline
\end{tabular}

kepustakaan ini dengan menentukan topik yang akan disampaikan, menentukan fokus penelitian, mengumpulkan artikel, buku, dan situs melalui internet, dan kemudian menyajikan data yang diperoleh. Sumber yang digunakan dalam membantu penulisan artikel ini berfokus pada tahapan perkembangan psikologis khususnya remaja, perubahan yang terjadi pada proses perkembangan ini khususnya secara psikologis yang menjadi latar belakang perilaku remaja, dan kenakalan remaja khususnya tawuran antar pelajar.

\section{HASIL DAN PEMBAHASAN Proses Perkembangan Psikologis Pada Masa Remaja}

Remaja merupakan salah satu tahapan yang harus dilewati setiap manusia, tahap ini merupakan transisi dari anak-anak ke tahap dewasa yang ditandai dengan percepatan munculnya perkembangan emosional, fisik, mental dan sosial (Lestari, 2013). Salah satu ciri pada tahapan ini adalah pubertas, ditandai dengan meningkatnya hormon seks hingga mencapai kematangan fungsi seksual pada individu (Dewi et al., 2017). Dalam tahap ini mereka mendapatkan tekanan untuk meniru norma atau nilai yang dipegang oleh teman sebayanya agar mendapatkan penerimaan dalam kelompok, hal ini dapat bersifat positif atau negatif (Nugrahaini, 2017). Menurut Erik Erikson dalam (Huriati, 2016) dikatakan bahwa hidup manusia merupakan urutan konflik psikososial dan krisis identitas merupakan salah satu tahapan yang dilalui saat remaja, hal ini dipengaruhi juga oleh stimulus sosial yang merupakan penggerak dinamik dalam pribadi seseorang. Untuk mendefinisikan remaja harus disesuaikan dengan budaya yang ada di masyarakat jadi ada kemungkinan perbedaan definisi remaja tiap negara. Fase perkembangan remaja dibagi menjadi tiga, yaitu (Unayah \& Sabarisman, 2015. hal.124-125) :

1. Adolensi dini, fase ini ditandai dengan meingkatnya Hasrat seksual yang diiringi dengan menurunnya tingkat ketekunan dan kreatifitas, hubungan mereka dengan orang tua mulai renggang dan mereka mulai mencari kelompok pertemanan. Perilaku yang mereka lakukan sering menyimpang dari nilai dan norma yang berlaku, serta bertindak tidak seperti biasanya.

2. Adolensi menengah, pada fase ini hubungan dengan lawan jenis mulai meningkat dan rasa tertarik akan sesuatu yang bersifat fantasi meningkat. Pada tahap ini juga remaja mulai menunjukan kebebasannya berpendapat dengan menyuarakan ketidaksukaannya baik kepada keluarga atau masyarakat.

3. Adolensi akhir, pada tahapan ini remaja akan lebih bisa menerima perbedaan yang ada di lingkungannya yang mungkin sebelumnya belum diterima oleh mereka. Memiliki kedudukan tertentu dan sikapnya mulai mirip dengan orang tuanya. Apabila kondisinya tidak stabil remaja pada tahapan ini perlu mendapatkan pertolongan atau layanan khusus dari orang sekitar atau professional.

Dari tahapan-tahapan diatas dapat dilihat bahwa setiap perubahan tahapan akan menciptakan pandangan atau pemikiran yang berbeda tentang bagaimana remaja harus berperilaku dalam masyarakat, dan bagaimana dia mengartikan nilai dan norma yang ada di sekitarnya. Pada tahapan ini individu yang gagal mencari identitas dirinya maka akan mengalami krisis identitas. Saat mengalami krisis identitas remaja cenderung melakukan kegiatan yang mengarah kepada kenakalan remaja (Huriati, 2016). Berikut merupakan ciri-ciri sosial pada remaja yang disampaikan oleh Sidik Jatmika (Saputro, 2018. hal.26) :

1. Remaja mulai menunjukkan kebebasannya melalui haknya untuk mengemukakakan 


\begin{tabular}{|c|c|c|c|c|}
\hline JURNAL & \multirow{2}{*}{ VOLUME 3} & \multirow{2}{*}{ NOMOR 1 } & HALAMAN 14-24 & $\begin{array}{l}\text { ISSN 2655-8823 }(p) \\
\text { ISSN 2656-1786 }(e)\end{array}$ \\
KOLABORASI RESOLUSI KONFLIK & ISS \\
\hline
\end{tabular}

pendapatnya sediri. Hal ini dapat menyebabkan ketegangan dan perselisihan dengan lingkungannya.

2. Remaja lebih mudah dipengaruhi oleh lingkungannya. Hal ini disebabkan oleh makin berkurangnya pengawasan orang tua, remaja cenderung melakukan berbagai kegiatan yang bahkan bertentangan dengan keluarganya.

3. Perubahan fisik yang terlihat, baik secara penampilan dan seksual. Perasaan seksual yang muncul dapat menyebabkan ketakutan, kebingungan, dan perasaan salah dan frustasi.

4. Dengan emosinya yang semakin meningkat, kepercayaan diri yang dimiliki remaja juga semakin meningkat. Hal ini menyebabkan sulitnya menerima nasihat dari orang-orang terdekatnya.

Pengaruh yang diambil dari lingkungan sekitarnya dan dibentuk sebagai pemahaman tentang apa yang seharusnya dilakukan (Malihah et al., 2014). Menurut (Nugrahaini, 2017), perkembangan remaja terjadi pada dua hal yaitu fisik dan psikologis. Salah satu perubahan psikologis yang terjadi adalah upaya melawan atau menentang peraturan yang dianggap membatasinya dalam melakukan kebebasan yang ditunjukkan dengan perilaku menyimpang (Unayah \& Sabarisman, 2015). Perubahan psikologis mencakup beberapa hal, antara lain (Nugrahaini, 2017. hal. 11-15) :

1. Konsep diri, mereka memiliki pemahaman lebih mengenai siapa dirinya dan apa yang membedakan dirinya dengan orang lain. Tidak hanya bersifat internal melainkan sebagai bentuk kontruksi sosial berdasarkan lingkungannya. Konsep diri akan terbentuk memalui interpretasi lingkungan dan pengalaman, penilaian orang lain, atribut, dan perilaku diri (Binti Muawanah, 2012).
2. Intelegensi, menurut Wechsler (Nugrahaini, 2017) intelegensi merupakan kemampuan individu dalam bertindak secara terarah dan menguasasi lingkungan secara efektif. Dengan makin banyaknya unsur pikiran yang digunakan maka tingka intelegensi makin tinggi. remaja mampu menciptakan kondisi fantasi dan berusaha menyelesaikannya dengan cara yang logis.

3. Emosi, pada tahapan remaja semakin banyak emosi yang dikeluarkan. Emosi yang dikeluarkan oleh remaja biasanya meledak-ledak dan sulit untuk dikendalikan, hal ini merupakan salah satu proses dalam membentuk identitas diri remaja. Kondisi emosi yang masih belum stabil dan upaya untuk mengekspresikan emosinya tersebut merupakan jalan untuk mencapai kedewasaan.

4. Peran sosial, terjadinya konflik peran sosial dalam dirinya bagaimana ia harus bertingkah sebagai orang dewasa namun, disaat yang bersamaan harus mengikuti kemauan orang tua. Banyak remaja yang kecewa karena tidak mendapatkan kemandirian yang diinginkan.

5. Peran gender, hampir sama dengan bagaimana ia mempelajari peran sosial dalam masyarakat, ia juga harus memahami perannya sebagai laki-laki atau perempuan dalam masyarakat.

6. Moral dan religi, moral berfungsi sebagai pedoman dalam menentukan apa yang baik dan buruk, dan remaja dalam tahapan ini membutuhkannya sebagai pedoman hidupnya. Agama merupakan salah satu faktor yang dapat mengendalikan masyarakat.

Dalam tahapan perkembangannya, terdapat dua macam gerakan yang 


\begin{tabular}{|c|c|c|c|c|}
\hline JURNAL & \multirow{2}{*}{ VOLUME 3} & \multirow{2}{*}{ NOMOR 1 } & \multirow{2}{*}{ HALAMAN 14-24 } & $\begin{array}{l}\text { ISSN 2655-8823 }(p) \\
\text { ISSN 2656-1786 }(e)\end{array}$ \\
\hline
\end{tabular}

dilakukan remaja yaitu, pergi meninggalkan orang tua dan menuju ke teman sebayanya (Unayah \& Sabarisman, 2015). Dari pernyataan tersebut dapat terlihat bahwa pada masa ini remaja mulai meninggalkan nilai dan norma yang diberikan oleh keluarganya dan berusaha mencari kebebasan dengan menuju teman sebayanya untuk mencari kesenangan. Peran orang tua dalam kehidupan sosial anak semakin berkurang dan tegantikan oleh teman sebayanya (Peter, 2015).

\section{Kenakalan Remaja dan Tawuran Antar Pelajar}

Kenakalan remaja bagaikan lingkaran setan yang tidak pernah berhenti. Hal ini sangat disayangkan karena remaja merupakan aset bangsa yang dikemudian hari akan menjadi pemimpin bangsa. Di Indonesia sendiri jumlah remaja sangat banyak bahkan, menjadi populasi tertinggi, karena Hal ini dapat menjadi hal yang positif atau menjadi bencana apabila tidak diarahkan dengan baik dan benar (Malihah et al., 2014). Sejalan dengan hal tersebut dikatakan bahwa nasib sebuah bangsa ditentukan oleh kualitas dan kemampuan generasi muda (Prasasti, 2017). Seperti pembahasan sebelumnya dijelaskan bahwa remaja merupakan peralihan dari tahap anak-anak ke dewasa, pada tahap ini individu banyak mengalami banyak perubahan baik secara fisik, sosial, dan psikologis, serta penuh dengan masalahmasalah yang ada (Prasasti, 2017).

Perilaku yang dilakukan remaja dan dianggap menyimpang dari nilai dan norma yang berlaku dianggap sebagai kenakalan remaja (SUMARA et al., 2017). Dikatakan oleh Kartono (2005), pakar patologis bahwa perilaku menyimpang atau dalam Bahasa inggris dikenal dengan juvenile delinquency merupakan gejala patologis yang disebabkan oleh pengabaian sosial sehingga, mereka melakukan perilaku yang menyimpang (Unayah \& Sabarisman, 2015). Menurut Santrock kenakalan remaja merupakan Tindakan yang tidak dapat diterima secara sosial sehingga disebut kriminalitas. Dari dua pengertian tersebut dapat disimpulkan bahwa kenakalan remaja merupakan perbuatan menyimpang dari nilai dan norma yang berlaku di masyarakat yang disebabkan oleh pengabaian sosial. Banyak jenis kenakalan remaja yang tidak kita sadari terjadi dalam lingkungan kita seperti, narkoba dan miras, perilaku seks bebas, tawuran antar pelajar, dll (Prasasti, 2017). Salah satu kenakalan remaja yang sering terjadi dan penting untuk dibahas adalah tawuran antar pelajar. Salah satu penyebab banyak remaja yang melakukan tindakan menyimpang ini adalah kegagalan dalam menentukan identitas dalam dirinya dan mengambil nilai yang salah dalam lingkungannya sehingga, terjerumus kepada kegiatan-kegiatan yang meresehkan warga.

Tawuran telah menjadi budaya di Indonesia, karena tawuran telah terjadi secara turun-menurun di kalangan remaja (Basri, 2015). Kelompok tawuran antar pelajar dimulai dengan kelompok bermain yang dinamis bersifat netral, baik, dan menyenangkan, kemudian menjadi kelompok yang berbahaya dan melakukan tindak kriminal (Yuliati, 2018). Tawuran pelajar merupakan kondisi berkelahinya dua kelompok siswa atau pelajar secara bersamaan disertai dengan kata-kata cacian dan merendahkan terhadap kelompok lawan (Kurniawan et al., 2009), kejadian ini bisa terjadi dimanapun dan kapanpun sehingga, sulit untuk diprediksi sebelumnya. Sangat disayangkan pelajar yang mengikuti tawuran, padahal sehrusnya sekolah merupakan wadah untuk menyiapkan generasi penerus bangsa (Eflaningrum, 2016).

Sekolah seharusnya merupakan tempat untuk mengembangkan kemampuan dan pembentukan watak siswa yang positif (Purba et al., 2015). Hal ini sangat memprihatinkan mengingat remaja merupakan aset bangsa di masa depan, Ketika seharusnya mereka belajar demi masa depannya mereka justru melakukan tindakan yang membahayakan dirinya dan lingkungan sekitar. Banyak hal yang 


\begin{tabular}{|c|c|c|c|c|}
\hline $\begin{array}{c}\text { JURNAL } \\
\text { KOLABORASI RESOLUSI KONFLIK }\end{array}$ & \multirow{2}{*}{ VOLUME 3} & \multirow{2}{*}{ NOMOR 1 } & HALAMAN 14-24 & $\begin{array}{l}\text { ISSN 2655-8823 }(p) \\
\text { ISSN 2656-1786 }(e)\end{array}$ \\
\hline
\end{tabular}

menjadi latar belakang terjadinya tawuran yang ada di Indonesia baik dari segi internal seperti, perkembangan fisik, mental dan kematangan emosi, dan eskternal seperti pengaruh lingkungan sekitar. Hal ini penting untuk diketahui agar kita dapat memahami dinamika sosial yang dialami remaja dan mengetahui tindakan pencegahan yang tepat untuk dilakukan.

\section{Latar Belakang Terjadinya Tawuran Antar Pelajar}

Tawuran antar pelajar disebabkan baik oleh faktor internal dan faktor eksternal, faktor tersebut saling mendukung satu sama lain, yang akhirnya menyebabkan terjadinya tawuran antar pelajar. Latar belakang terjadinya tawuran yang pertama adalah krisis identitas, menurut Hurlock (1980) dalam (Palupi, 2013. hal. 49) dikatakan bahwa remaja merupakan masa peralihan atau transisi. Masa transisi ini lah yang menyebabkan terjadinya krisis identitas yang ditandai dengan perilaku kenakalan remaja (Palupi, 2013).

Kriris identitas merupakan tahapan dalam mengambil keputusan atas permasalahan yang berkaitan dengan pertanyaan-pertanyaan yang ada pada dirinya (Huriati, 2016). Saat remaja mengalami krisis identitas cenderung melakukan tindakan destruktif yang mengarah kepada kenakalan remaja (Huriati, 2016).

Kedua, emosi yang bergejolak, emosi berkaitan dengan perubahan fisiologis dan pikiran, emosi merupakan motivator dalam perilaku manusia (Yulianto, 2014), hal ini sejalan dengan pernyataan Goleman (2002) dalam (Yulianto, 2014. hal. 14) bahwa emosi merupakan dorongan individu untuk memberikan respon atas stimulus yang diberikan. Kondisi emosi mereka yang muncul pada tahapan remaja masih meledak-ledak, sulit dikendalikan, dan emosi masih belum stabil (Nugrahaini, 2017). Maka, diperlukan kemampuan pengendalian emosi untuk mempertahankan batasan emosi dan memahami emosinya agar dapat diarahkan kepada kegiatan positif (Binti Muawanah, 2012).

Ketiga, kurangnya spirtualitas dalam diri remaja, agama merupakan pedoman dalam menjalankan hidup yang terlihat dari upaya menginternalisasi ajaran agama dalam perilaku sehari-hari, sehingga dapat diasumsikan bahwa remaja yang melakukan kenakalan remaja memiliki tingkat spirtualitas yang rendah (Palupi, 2013). Hal ini sejalan dengan yang diungkapkan Sudarsono (2018) bahwa anak-anak yang melakukan kenakalan remaja sebagian besar kurang memahami norma agama bahkan lalai dalam menunaikan perinatah agama (Palupi, 2013. hal. 50). Kurangnya penerapan ilmu agama akan menyebabkan rendahnya etika moral dan kontrol diri yang dimiliki remaja (Huriati, 2016). Menurut penelitian yang dilakukan Rosalina \& Audrie (2007) dalam (Mangestuti \& Aziz, 2017) dikatakan bahwa spirtulitas berdampak dalam mengatasi masalah-masalah yang berkaitan dengan tugas-tugas perkembangan remaja.

Keempat, pengaruh konformitas yang kuat dalam lingkungan pergaulan, menurut Furhman (1990) konformitas adalah kecenderungan menerima dan mengikuti norma yang dibuat kelompoknya (Kurniawan et al., 2009. hal. 88). Menurut Santrock (2003) dalam (Kurniawan et al., 2009. hal. 86) konformitas muncul ketika individu meniru perilaku orang lain karena adanya tekanan yang nyata atau hanya sebatas bayangan mereka. Terdapat konformitas positif dan negatif yang dapat diterima remaja dari teman sebayanya konformitas negatif akan mengarahkan remaja kepada perilaku kenakalan remaja salah satunya tawuran antar pelajar (Kurniawan et al., 2009). Takut akan penolakan sosial menyebabkan mereka akan melakukan apapun agar dapat diterima di kelompok tertentu (Kurniawan et al., 2009).

Kelima, kurangnya peran orang tua, menurut Kartini Kartono (1986) dalam (Andriyani, 2020. hal.96) dikatakan bahwa salah satu penyebab terjadinya kenakalan 


\begin{tabular}{|c|c|c|c|c|}
\hline JURNAL & \multirow{2}{*}{ VOLUME 3} & \multirow{2}{*}{ NOMOR 1 } & HALAMAN 14-24 & $\begin{array}{l}\text { ISSN 2655-8823 }(p) \\
\text { ISSN 2656-1786 }(e)\end{array}$ \\
KOLABORASI RESOLUSI KONFLIK & ISS \\
\hline
\end{tabular}

remaja adalah kurang perhatian, kasih saying, dan tuntututan Pendidikan dari orang tua, karena sibuk dengan masalahnya sendiri. Kurangnya kendali orang tua dalam keluarga akan menyebabkan perilaku anak yang acuh dan cuek (Andriyani, 2020). Menurut Hirschi (Fitriana, 2016) dikatakan bahwa salah satu penyebab kenakalan remaja adalah tidak berfungsinya peran orang tua sebagai contoh yang baik bagi anak.

Terakhir, budaya yang sudah turuntemurun, prasangka yang dimiliki siswa merupakan hasil belajar terhadap lingkungannya, sejalan dengan pendapat Tubagus (1999) prasangka telah ada secara turun-termurun dari angkatan ke angkatan berikutnya (Kurniawan et al., 2009. hal. 90). Senior menanamkan prasangka kepada adik kelas terhadap kelompok pelajar yang lain, prasangka yang diberikan cenderung tidak didasarkan pada fakta objektif, melainkan fakta yang bersifat subyektif (Kurniawan et al., 2009).

\section{Upaya Pencegahan Tawuran Antar Pelajar}

Dari penyebab yang telah kita uraikan sebelumnya terdapat upaya yang dapat mengurangi atau mencegah terjadinya tawuran pelajar di kemudian hari. upaya yang dapat kita lakukan antara lain, meningkatkan keberfungsian keluarga, keluarga merupakan unit sosial terkecil yang berperan dalam perkembangan individu, dan keluarga merupakan pembentuk karakter utama pada anak (Christian \& Jatmika, 2018). Dengan keluarga yang berfungsi akan menciptakan hubungan yang harmonis dan serasi (Andriyani, 2020). Keberfungsian ini dilihat dari beberapa prinsip yaitu menyusun standar aturan bagi anak, memberikan hadiah atas pencapaian, menjelaskan perilaku yang benar dan salah dengan alasan, berkomunikasi dengan anak untuk menghargai dirinya dan lingkungannya (Andriyani, 2020). Komunikasi dan interaksi antara anak dan orang tua merupakan hal penting dalam keluarga (Andriyani, 2020).

Kedua, mengembangkan ekstrakuliker sebagai wadah untuk mengembangkan potensi siswa. Ekstrakuliler merupakan kegiatan yang dilakukan di luar jam sekolah untuk mengembangkan bakat dan potensi siswa (Hidayati, 2014). Salah satu tujuan diadakannya ekstrakulikuler dalam Permendiknas No. 39 Tahun 2018 adalah memantapkan kepribadian siswa untuk mewujudkan ketahanan sekolah sebagai lingkungan pendidikan sehingga terhindar dari usaha dan pengaruh negatuf dan bertentangan dengan tujuan pendidikan. Ekstrakulikuler bela diri merupakan salah satu bentuk esktrakulikuler yang memberikan peranan besar dalam mengurangi kenakalan remaja (Rangga Prastyana, 2008). Menurut Jamal Ma'mur Asmani (2012) dalam (Elhesmi et al., 2013) dikatakan bahwa pelajar yang gagal dalam menggunakan potensinya maka masa depannya akan terancam gagal sedangkan, pelajar yang dapat memanfaatkan potensinya berpotensi untuk sukses di masa depan.

Ketiga, memberikan layanan bimbingan dan konseling yang dilakukan oleh guru bimbingan konseling, layanan yang diberikan didasarkan pada perkembangan dan kebutuhan murid, serta disesuaikan dengan permasalahan yang dihadapi murid (Hariri, 2020). Layanan yang diberikan bisa bersifat preventif (pencegahan) atau kuratif (pengentasan) (Sa'dullah \& Arif, 2020). Peranan yang dilakukan guru bimbingan konseling adalah memberikan pemahaman mengenai informasi yang luas berkaitan dengan nilainilai, budaya, sosial, hukum dan agama agar terciptanya karakter siswa yang positif (Elhesmi et al., 2013).

Keempat, meningkatkan spiritualitas dalam diri remaja, Menurut penelitian yang dilakukan (Apriyanti, 2017), dikatakan bahwa semakin tinggi tingkat spitualitas maka akan semakin kecil kemungkinan terjadinya kenakaln remaja. Hal tersebut sejalan dengan yang dikatakan oleh 


\begin{tabular}{|c|c|c|c|c|}
\hline $\begin{array}{c}\text { JURNAL } \\
\text { KOLABORASI RESOLUSI KONFLIK }\end{array}$ & \multirow{2}{*}{ VOLUME 3} & \multirow{2}{*}{ NOMOR 1 } & HALAMAN 14-24 & $\begin{array}{l}\text { ISSN 2655-8823 }(p) \\
\text { ISSN 2656-1786 }(e)\end{array}$ \\
\hline
\end{tabular}

Jalaluddin (2002) bahwa remaja yang memiliki tingkat spirtualitas tinggi akan menunjukkan perilaku yang religious pula, sebaliknya remaja yang memiliki religius rendah akan menunjukkan perilaku yang jauh dari religius pula (Palupi, 2013. hal. 51) Bimbingan agama yang intensif akan membantu siswa dalam memahami agama lebih baik dan dapat mampu mengamalkannya pada kehidupan seharihari (Andria, 2016).

Kelima, sosialisasi kebijakan sekolah mengenai tawuran antar pelajar, implementasi kebijakan sekolah dipengaruhi oleh komunikasi antara pihak sekolah dengan siswa (Alfian, 2008). Kebijakan sekolah merupakan seluruh proses yang diciptakan untuk mewujudkan tercapainya visi dan misi sekolah (Alfian, 2008). Selain itu, kebijakan sekolah diciptakan untuk membatasi perilaku siswa agar terhindar dari perilaku kenakalan remaja (Alfian, 2008). Dari hasil studi kepustakaan yang dilakukan mengenai hubungan perkembangan psikologis remaja dengan perilaku tawuran antar pelajar menunjukkan bahwa perubahan yang terjadi pada fase ini memberikan pengaruh terhadap perilaku tawuran antar pelajar sebagai bentuk krisis identitas yang dialami oleh remaja.

\section{KESIMPULAN DAN SARAN Kesimpulan}

Berdasarkan hasil kajian pustaka yang dilakukan dalam penelitian ini diperoleh kesimpulan bahwa proses perkembangan pada tahapan remaja sangat berhubungan terhadap perilaku kenakalan remaja khususnya tawuran antar pelajar. Remaja merupakan tahapan peralihan dari masa anak-anak menuju kedewasaan dan dalam proses ini mereka banyak mengalami perubahan psikologis dalam dirinya, mereka adalah calon pemimpin bangsa di masa yang akan datang. Krisis identitas yang sedang mereka alami merupakan salah satu proses yang menyebabkan mereka masih mencari jawaban atas pertanyaan yang ada tentang masalahnya. Selain itu, kondisi emosional mereka yang belum stabil dan masih meledak-ledak juga merupakan faktor yang menyebabkan mereka melakukan perilaku menyimpang. Mereka masih belum bisa mentukan konsep atas diri mereka sendiri secara sempurna, dengan pengalaman-pengalaman dan interpretasi dari lingkungan sekitar akan membentuk mereka sebagai proses menuju kedewasaan.

Lingkungan memiliki peran besar dalam menentukan perilaku remaja, kondisi lingkungan yang negatif akan membawa kepada perilaku remaja yang negatif dan sebaliknya, apabila mereka dalam lingkungan yang positif maka akan tercipta perilaku yang positif. Aspek spiritual memiliki peranan penting dalam menciptakan perilaku remaja yang positif, dengan memiliki aspek spiritual dalam diri individu akan menjadi pedoman dan bertindak dan berperilaku dalam lingkungan sekitar.

Terdapat beberapa hal yang dapat dilakukan guna mencegah atau mengurangi terjadinya tawuran antar pelajar, antara lain meningkatkan keberfungsian keluarga, mengembangkan ekstrakulikuler sekolah agar siswa dapat menyalurkan emosinya dengan kegiatan yang positif, layanan konseling oleh guru bimbingan konseling untuk memberikan gambaran luas berkaitan dengan nilai-nilai, budaya, sosial, hukum dan agama agar terciptanya karakter siswa yang positif, meningkatkan spirtualitas anak melalui pendidikan agama baik oleh orang tua atau guru sekolah, dan sosialisasi peraturan sekolah sebagai upaya mencegah terjadinya tawuran antar pelajar.

\section{Saran}

Berdasarkan simpulan diatas, maka saran yang diberikan dalam penelitian ini adalah pemerintah perlu untuk menjadikan kenakalan remaja khususnya tawuran antar pelajar sebagai perhatian penting, karena remaja merupakan calon pemimpin bangsa di masa yang akan datang. Hal ini perlu didukung juga oleh orang terdekat yang ada di lingkungan remaja antara lain keluarga, 


\begin{tabular}{|c|c|c|c|c|}
\hline JURNAL & \multirow{2}{*}{ VOLUME 3} & NOMOR 1 & HALAMAN 14-24 & $\begin{array}{l}\text { ISSN 2655-8823 }(p) \\
\text { ISSN 2656-1786 }(e)\end{array}$ \\
KOLABORASI RESOLUSI KONFLIK
\end{tabular}

guru, teman sebaya dll, dalam menciptakan lingkungan yang positif dalam proses pembetukan diri remaja. Upaya yang dapat dilakukan antara lain:

1. Meningkatkan keberfungsian keluarga sebagai lingkungan terdekat anak.

2. Mengembangkan ekstrakulikuler sebagai wadah bagi siswa menyalurkan ekpresinya.

3. Memberikan layanan dan bimbingan konseling kepada siswa yang memiliki hambatan dan layanan yang diberikan disesuaikan dengan permasalahan yang dimiliki siswa.

4. Meningkatkan spiritualitas kepada anak baik melalui orang tua atau guru di sekolah sejak dini agar anak memiliki panduan dalam menjalankan kehidupan dan terhindar dari perilaku kenakalan remaja.

5. Sosialisasi kebijakan sekolah terkait dengan peraturan mengenai tawuran antar pelajar sebagai upaya preventif.

\section{DAFTAR PUSTAKA}

Agustina, A., \& Appulembang, Y. A. (2017). Pengaruh Pola Asuh terhadap Kualitas Hidup Siswa Pelaku Tawuran. Jurnal Muara Ilmu Sosial, Humaniora, Dan Seni, $1(1), \quad 210$. https://doi.org/10.24912/jmishumsen.v $1 \mathrm{i} 1.351$

Agustina, R., Rachmawati, Y., Silviliyana, M., Annisa, L., \& Wilson, H. (2019). STATISTIK PEMUDA INDONESIA 2019. Badan Pusat Statistik.

Alfian, Y. (2008). Implementasi Kebijakan Sekolah Dalam Menangani Kenakalan Siswa. Jurnal Kajian Moral Dan Kewarganegaraan., 6, 444-458.

Andria, T. (2016). The Role of Religious Guidance in Overcome Juvenile Delinquency Peran Bimbingan Keagamaan dalam Penanggulangan Kenakalan Remaja. Bimas Islam, 9(1), 151-206.
Andriyani, J. (2020). Peran Lingkungan Keluarga Dalam Mengatasi Kenakalan Remaja. At-Taujih: Bimbingan Dan Konseling Islam, 3(1), 86. https://doi.org/10.22373/taujih.v3i1.72 35

Anjari, W. (2013). Tawuran Pelajar Dalam Perspektif Kriminologis, Hukum Pidana, Dan Pendidikan. Majalah Ilmiah Widya - eJournal.Jurwidyakop3.Com, Fakultas Hukum, Universitas 17 Agustus 1945, Jakarta, 324, 34-40. http://download.portalgaruda.org/articl e.php? article $=250324 \& \mathrm{val}=6691 \&$ title $=$ TAWURAN PELAJAR DALAM PERSPEKTIF KRIMINOLOGIS, HUKUM PIDANA, DAN PENDIDIKAN

Apriyanti, M. E. (2017). Peran Pendidikan Agama dan Perhatian Orang Tua Dalam Mencegah Penyalahgunaan Narkoba. Faktor Jurnal Ilmiah Kependidikan, 4(2), 133-142.

Arif, S., Wanda, A., \& Masudi, A. (2013). Aplikasi Administrasi Perpustakaan Berbasis Web Smk Swasta Brigjend Katamso Medan. Jurnal Ilmiah Saintikom, 12(1), 25-36.

Artini, B. (2018). Analisis Faktor Yang Memengaruhi Kenakalan Remaja. Jurnal Keperawatan, 7(1). https://doi.org/10.47560/kep.v7i1.117

Basri, A. (2015). FENOMENA TAWURAN ANTAR PELAJAR DAN INTERVENSINYA. Hisbah: Jurnal Bimbingan Konseling Dan Dakwah Islam, 12(1), 1-25. file://C:/Users/youhe/Downloads/kdoc _o_00042_01.pdf

Binti Muawanah, L. (2012). Kematangan Emosi, Konsep Diri Dan Kenakalan Remaja. Persona:Jurnal Psikologi Indonesia, 1(1), 6-14. https://doi.org/10.30996/persona.v1i1. 9

Christian, C. V., \& Jatmika, D. (2018). Pengaruh Persepsi Komunikasi Efektif Dengan Orang Tua Terhadap Kecenderungan Kenakalan Remaja Di 


\begin{tabular}{|c|c|c|c|c|}
\hline JURNAL & \multirow{2}{*}{ NOMOR 1 } & \multirow{2}{*}{ HALAMAN 14-24 } & $\begin{array}{l}\text { ISSN 2655-8823 }(p) \\
\text { ISSN 2656-1786 }(e)\end{array}$ \\
\hline
\end{tabular}

Sma X Jakarta. Jurnal Psikologi Ulayat, 5(2), 157-168. https://doi.org/10.24854/jpu02018-137

Dewi, R., Hanifah, H., Hidayati, E. (2017). Prosiding Simposium LXXIII Masalah Kesehatan Neonatus sampai Remaja. http://staff.ui.ac.id/system/files/users/n ajib.advani/publication/pkb_ika_ke_73 _2017_kiat_menegakkan_diagnosis_pe nyakit_jantung_bawaa.pdf\#page $=160$

Eflaningrum, A. (2016). Realitas Kekerasan Pelajar SMA di Kota Yogyakarta. Meneguhkan Peran Penelitian Dan Pengabdian Kepada Masyarakat Dalam Memuliakan Martabat Manusia, 535-545.

Elhesmi, S., S, N., \& Ibrahim, I. (2013). Peran Guru BK Dan Guru Mata Pelajaran dalam Mencegah Tawuran antar Pelajar. Konselor, 2(3). https://doi.org/10.24036/020132321390-00

Fitriana, S. (2016). Sikap sebagai upaya preventif tawuran antar pelajar. Seminar Nasional Bimbingan Konseling, 52-64.

Hariri, I. (2020). MENANGGULANGI KENAKALAN SISWA THE CONCEPT OF GUIDANCE AND COUNSELING IN OVERCOMING. 3(2), 14-22.

Hidayati, N. (2014). Peran Kegiatan Ekstrakurikuler dalam Menumbuhksn Kedisiplinan Siswa di SMA Negeri 5 Tangerang. UNIVERSITAS ISLAM NEGERI (UIN) SYARIF HIDAYATULLAH JAKARTA.

Huriati, N. H. \&. (2016). Krisis Identitas Diri pada Remaja. Sulesana, 10(1), 49 62.

Kurniawan, S., Mutho, A., \& Rois, M. (2009). Tawuran, Prasangka Terhadap Kelompok Siswa Sekolah Lain, Serta Konformitas Pada Kelompok Teman Sebaya. E-Journal Psikology, Unnisula, 4(2), 85-94.

Lestari, N. M. S. D. (2013). Pengaruh dismenorea pada remaja. Seminar Nasional FMIPA UNDIKSHA III, 323329.

ejournal.undiksha.ac.id/index.php/sem nasmipa/article/download

Malihah, E., Wilodati, \& Jerry, G. (2014). Kenakalan Remaja Akibat Kelompok Pertemanan Siswa. Forum Ilmu Sosial, 41(1).

https://doi.org/10.15294/fis.v41i1.5373

Mangestuti, R., \& Aziz, R. (2017). Kecerdasan Emosi, Kecerdasan Spiritual dan Agresivitas pada Remaja. Jurnal Psikoislamika, 13(1), 1-11. https://www.m-

culture.go.th/mculture th/download/ki ng9/Glossary_about_HM_King_Bhum ibol_Adulyadej's_Funeral.pdf

Mantalean, V. (2020). Remaja Tewas Dibacok Dalam Tawuran di Tengah Pandemi Covid-19. Kompas.Com. https://megapolitan.kompas.com/read/ 2020/10/01/20090811/remaja-tewasdibacok-dalam-tawuran-di-tengahpandemi-covid-19

Nugrahaini, F. B. (2017). Faktor - Faktor Yang Mempengaruhi Kenakalan Remaja (Tawuran Pelajar) Di Kota Semarang. Universitas Negeri Semarang.

Palupi, A. O. (2013). Remaja Pada Siswa Kelas Viii SMP Negeri 02 Slawi Kabupaten Tegal. Universitas Negeri Semarang.

Peter, R. (2015). Peran Orangtua dalam Krisis Remaja. Humaniora, 6(4), 453. https://doi.org/10.21512/humaniora.v6i 4.3374

Prasasti, S. (2017). Kenakalan remaja dan faktor penyebabnya. Seminar Nasional Bimbingan Dan Konseling, 1(1), 2845.

prosiding.unipma.ac.id/index.php/SNB $\mathrm{K} /$ article/download/110/109

Purba, H., Holilulloh, \& Nurmalisa, Y. (2015). PERCEPTION STUDENT REGIMENT LAMPUNG UNIVERSITY ON THE PHENOMENON FIGHTING BETWEEN STUDENT. Jurnal Kultur Demokrasi, 4(5).

Rangga Prastyana, B. (2008). Peran Exstrakurikuler Pecak Silat dalam Meminimalisir Kenakalan Remaja di 


\begin{tabular}{|c|c|c|c|c|}
\hline JURNAL & \multirow{2}{*}{ VOLUME 3} & \multirow{2}{*}{ NOMOR 1} & HALAMAN 14-24 & $\begin{array}{l}\text { ISSN 2655-8823 }(p) \\
\text { ISSN 2656-1786 }(e)\end{array}$ \\
\hline KOLABORASI RESOLUSI KONFLIK
\end{tabular}

Sekolah. Jurnal Buana Pendidikan, 22(22), 28-50.

Riswanto, D. (2019). Peran Konselor dalam Mereduksi Tingkat Kenakalan Remaja di Kabupaten Pandeglang. Jurnal RAP (Riset Aktual Psikologi Universitas Negeri Padang), 10(2), 171. https://doi.org/10.24036/rapun.v10i2.1 06065

Sa'dullah, A., \& Arif, S. (2020). PELAKSANAAN LAYANAN BIMBINGAN DAN KONSELING DALAM MENANGGULANGI KENAKALAN DI SMP NEGERI 3 PAMEKASAN. Edu Consilium, 1(1), 13-22.

https://core.ac.uk/download/pdf/28723 0838.pdf

Saputro, K. Z. (2018). Memahami Ciri dan Tugas Perkembangan Masa Remaja. Aplikasia: Jurnal Aplikasi Ilmu-Ilmu Agama, $\quad 17(1), \quad 25$. https://oi.org/10.14421/aplikasia.v17i 1.1362

SUMARA, D. S., HUMAEDI, S., \& SANTOSO, M. B. (2017). Kenakalan Remaja Dan Penanganannya. Prosiding Penelitian Dan Pengabdian Kepada Masyarakat, 4(2). https://doi.org/10.24198/jppm.v4i2.143
93

Tianingrum, N. A., \& Nurjannah, U. (2020). Pengaruh Teman Sebaya Terhadap Perilaku Kenakalan Remaja Sekolah Di Samarinda. Jurnal Dunia Kesmas, 8(4), 275-282. https://doi.org/10.33024/jdk.v8i4.2270

Unayah, N., \& Sabarisman, M. (2015). the Phenomenon of Juvenile Delinquency and Criminality. Sosio Informa, 1(2), 121-140.

https://doi.org/http://dx.doi.org/10.221 46/jpsi.6959

Yulianto, D. (2014). HUBUNGAN ANTARA KONSEP DIRI DAN KECERDASAN EMOSI DENGAN KENAKALAN REMAJA. Nusantara of Research: Jurnal Hasil-Hasil Penelitian Universitas Nusantara PGRI Kediri, 1(1), 76-82. https://ojs.unpkediri.ac.id/index.php/ef ektor/article/view/23

Yuliati, N. (2018). Mencegah Tindak Kekerasan Dan Tawuran Antar Pelajar Melalui Pengembangan Program Pelatihan Social Perspective Taking Di Sekolah. Psympathic: Jurnal Ilmiah Psikologi, 6(1), 787-804. https://doi.org/10.15575/psy.v6i1.2136 